\title{
並征エネルギーを制御した塩塐分子線による シリコンのエッチング后応
}

\author{
寺 岡 有 殿・西山岩男

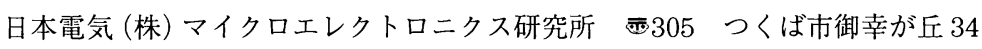

(1995年 3 月30日受理)

\section{Etching Reactions on Silicon Surfaces by Translational-Energy-Controlled Chlorine Molecular Beams}

\author{
Yuden Teraoka and Iwao Nishiyama \\ NEC Corporation, Microelectronics Research Laboratories \\ 34 Miyukigaoka, Tsukuba, Ibaraki 305
}

(Received March 30, 1995)

\begin{abstract}
近年，超熱エネルギー領域の並進エネルギーをもつ中性分子線を用いたエッチング反応においても，並進エ ネルギーによって反応速度が増加する効果が見出されている。本稿では塩素とシリコンの表面反応を例にとり， 分子線の並進エネルギーを制御する方法, 塩素吸着構造とその熱的安定性, 初期付着確率とエッチレートに対 する塩素分子の並進エネルギーの影響, 並進エネルギー誘起エッチングの反応間値 / 活性化エネルギーの測定 を中心に，塩素原子線による反応も含めて最近の研究例を紹介する。
\end{abstract}

\section{1. はじめに}

固体表面の構成元素そのものが生成物に組入れられて 脱離するような表面反応過程における入射分子の並進工 ネルギーの役割を理解することは, 純粋な表面化学とし てのみならず, 半導体の超微細加工の観点からもきわめ て興味深い。われわれは中性分子線による半導体の無損 傷かつ垂直エッチングの可能性を探るため, 超熱エネル ギー領域の並進エネルギーをもつ塩素分子とシリコンと の反応性を研究してきた。これまでにエッチング反応が 並進エネルギーによって誘起されることを見出し, 数 $\mathrm{eV}$ 程度の並進エネルギーでも垂直に近いエッチング形 状が可能であることを実証している ${ }^{1,2)}$ 。本稿では, 他 の研究グループの成果も含めて, 最近数年間に行われた 中性分子線を用いたシリコンのエッチング反応に関し て, 特にノズル分子線の並進エネルギーを制御する方 法, 塩素吸着構造とその熱的安定性に関するこれまでの 知見, 初期付着確率とエッチレートに対する塩素分子の 並進エネルギーの影響を中心に, 塩素原子線を用いた表
面反応も含めて最近の研究例を紹介する。

\section{2. ノズル分子線法による並進エネルギーの 制御方法}

超熱エネルギー領域の並進エネルギーをもつ分子線を 得るための方法としては, ノズル分子線法 ${ }^{3-5)}$, レーザー 蒸発法6.7), レーザー爆発法8.9)が知られ，いずれもエッ チング研究に用いられている。本稿では最も広く用いら れているノズル分子線法について述べる。この方法で は, 典型的には数気圧のガスを数十 $\mu \mathrm{m}$ 程度の小穴から 真空中に噴出させる。その際にガスは断熱膨張するた め, ガス分子の内部温度が低下して速度分布も狭くなる という特徵がある。分子分光の実験には前者の特徵が活 かされ, 原子衝突の実験には後者の特徵が利用されてい る。並進エネルギー分布のピーク值はノズル温度に比例 するので, ノズル温度を高くすることで並進エネルギー を大きくできる。しかし, 高温では振動励起準位の占有 率も大きくなるため, 並進エネルギーと振動エネルギー を独立に制御した実験を行うためにはシード分子線法を 
用いる。この方法では質量の異なる混合ガスを噴出させ る。マッハ数をほぼ定に保てば, 速度分布はノズル温 度, 混合ガスの換算質量, 換算比熱比で決まるので, , ズル温度を一定にしてガスの混合比を変化させることで 振動状態にはほとんど影響を与えずに並進エネルギーを 変化させることができる。また逆に，ノズル温度と混合 比を同時に変えることで並進エネルギーを一定に保った まま振動準位の占有率を変化させることもできる。エッ チング反応実験では, 通常は軽い希ガスに重いハロゲン ガスを少量混合する。ハロゲンガスの速度分布は希ガス 単体のそれに近づくので, 八ロゲンガス分子は超熱エネ ルギー領域の並進エネルギーをもちうる。

実例としてわれわれの用いているノズル分子線装置 の主要部分をFig. 1 に示す。真空チェンバは 3 室直列 の差動排気系となっている。ガス導入室でノズルから 連続的にガスを噴出させる。ノズルのオリフィスから 数 $\mathrm{mm}$ 下流にスキマーを設置して分子線の中心軸を切り 出す。中間室と反応室の間にゲートバルブを設けて反応 室への分子線の導入を制御する。反応室の到達圧力は $4 \times 10^{-10}$ Torr で, 反応中は $1 \times 10^{-6} \mathrm{Torr}$ 程度になる。， ズルは PBN 製である。ノズルヒーターはグラファイト の発熱膜を PBN 膜で挟み込み, 断面がサンドイッチ構 造の円筒型のものを用いた。これをノズルにかぶせて直 流加熱で $1700 \mathrm{~K}$ 程度までの昇温を確認している。オリ フィスの直径は $100 \mu \mathrm{m}$ である。スキマーは $\mathrm{Ni}$ 製の市販 品 (Beam Dynamics 社製) で, 先端の口径は $1 \mathrm{~mm}$ であ る。オリフィスとスキマー間の距離は分子線の強度が極 大を示すように約 $6 \mathrm{~mm}$ に調整した。反応性ガスとして は塩素ガス, キャリアガスとしてはアルゴンとヘリウム を用いた。それぞれの供給量を個別の流量計で制御し， 混合してノズルに供給した。ノズルの背圧はガス流量と ノズル温度に依存するが, 数気圧程度である。塩素ガス
の混合比は数\% 程度である。

われわれの実験では，実際にエッチング形状を観察す る必要から比較的大きな強度 $\left(3 \times 10^{16} \mathrm{molecules} / \mathrm{cm}^{2} / \mathrm{s}\right.$ 程度) の連続分子線を用いたが, 表面反応解析に特化し た実験を行う場合には 2 けたほど小さい強度の分子線を パルス化して用いる場合が多い。パルス化するためには 電磁弁型のノズルを用いる例もあるが, 数十 $\mu \mathrm{s}$ 以下の 短いパルス幅を得るのが困難で，また，高温では動作が 保証されないため, 高温ノズルを用いる場合には中間室 にチョッパを設ける方法をとる10)。パルス分子線と作動 排気質量分析器を併用すれば, 散乱分子や分子線に同期 した脱離生成物の観測に有効である11。

\section{3. 塩素分子/シリコン系エッチング反応の 並進エネルギー依存性}

\section{1 初期付着確率}

分子線を用いて実験的に初期付着確率を決めるには King と Wells の方法 ${ }^{12)}$ がよく用いられている。この方法 では, 試料表面の前に遮蔽板を置いて分子線を導入す る。このとき試料表面が清浄に保たれるほど分子線強度 が小さく，また，排気速度が十分大きくなければならな い。遮蔽板を除去すると分子線が直接試料表面に当って 吸着するため, 分圧が瞬間的に下がる。その変化量を $P$ とする。その後飽和吸着に近づくにつれて分圧は回復す る。分子線の供給を止めると分圧はきわめて低くなる。 この変化量 $P_{0}$ を分子線が $100 \%$ 吸着した状態に相当す ると解釈して $P / P_{0}$ を初期付着確率と見なす。

Kummel らは Si(100)2×1 面と $\operatorname{Si}(111) 7 \times 7$ 面で塩素 分子の初期付着確率の並進エネルギー依存性を測定し た ${ }^{13)}$ 。表面温度は $250 \mathrm{~K}$ から $900 \mathrm{~K}$, 並進エネルギーは $0.038 \mathrm{eV}$ から $0.66 \mathrm{eV}$ の範囲で行った。Fig. 2 に(100) $2 \times 1$

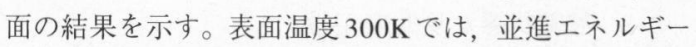

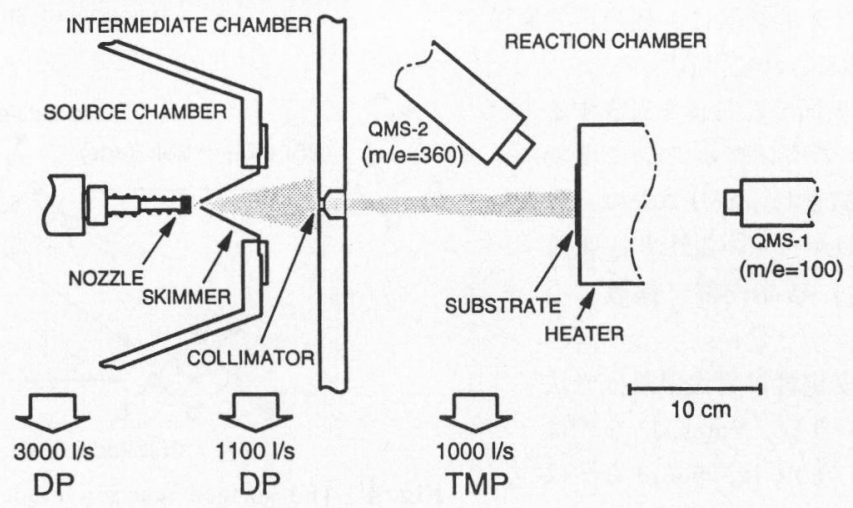

Fig. 1 The diagram showing a main part of the nozzle beam apparatus used in our work ${ }^{1}$. 


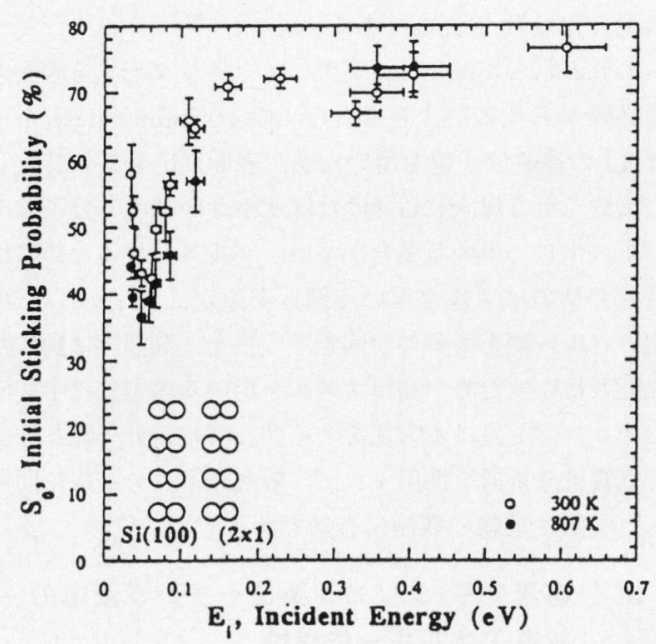

Fig. 2 The initial sticking probabilities of normal incidence $\mathrm{Cl}_{2}$ at the surface temperatures of 300 and $807 \mathrm{~K}$ for $\mathrm{Si}(100)(2 \times 1)$ surface $\left.{ }^{13}\right)$.

が $0.038 \mathrm{eV}$ のとき初期付着確率は $58 \%$ であるが， $0.045 \mathrm{eV}$ では 42\%にまで低下して負の依存性を示した。さらに， $0.16 \mathrm{eV}$ では逆に $72 \%$ まで増加して正の依存性を見せて いる。負の依存性を示す並進エネルギー領域での初期 付着確率は表面温度を上げると単調に減少するのに対 して, 正の依存性を示す並進エネルギー領域での初期 付着確率は表面温度に依存しない。これらの結果から， $0.038 \mathrm{eV} \sim 0.045 \mathrm{eV}$ 間の負の依存性は前駆体を経由した 化学吸着 (precursor-mediated chemisorption), $0.045 \mathrm{eV}$ 以上で見られる正の依存性は直接的に活性障壁を越える 化学吸着 (direct activated chemisorption) と解釈されて いる。いずれにしろ塩素分子は最終的には最表面のシリ コン原子に解離吸着する。

\section{2 吸着状態と熱的安定性}

塩素分子の解離吸着構造は, $\operatorname{Si}(111) 7 \times 7$ 面の場合, アドアトムのダングリングボンドに 1 個の塩素原子が 垂直に結合していると考えられている14)。一方， $\operatorname{Si}(100) 2 \times 1$ 面では，最表面で二量体を形成する 各シリコン原子のダングリングボンドに塩素 原子が 1 個ずつ斜めに結合し，シリコンの二量 体は保存されることがわかっている14 16)。吸着 した塩素原子は自発的に結晶内部に拡散しな い17-19)。

この吸着構造の熱的安定性は昇温脱離分光法 (TDS) から知ることができる。Yates, Jr. ら ${ }^{20)}$ は $825 \mathrm{~K}$ に, Engel ら ${ }^{21)}$ は $960 \mathrm{~K} に$, Foord ら ${ }^{22)} は$ $900 \mathrm{~K}$ 付近に脱離ピークを観測している。このよ うに脱離温度には差が認められるものの, 塩素
が解離吸着した Si(111),(100) 面からはおおむね $900 \mathrm{~K}$ 前 後で $\mathrm{SiCl}_{2}$ が熱脱離すると考えてよい。逆に $900 \mathrm{~K}$ 以下 では終端塩素の吸着構造は保持されるため, 塩素ガスを 供給しても実際にエッチング反応はほとんど起こらな w。

\section{3 常温ノズル分子線を用いたエッチング反応}

熱エネルギー程度の並進エネルギーをもつ塩素分子線 を用いて, 反応温度や生成物の同定を行う研究として は, 古くはMadix らが分子線緩和分光法 (MBRS) を適 用した例がある23)。Si(100)，(111)の場合には表面温度 $800 \mathrm{~K}$ 以上で $\mathrm{SiCl}_{2}$ の脱離が観測された。Karahashiらはパ

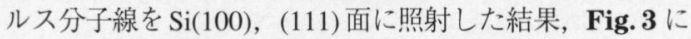
示すように, $900 \mathrm{~K}$ 程度から $\mathrm{SiCl}_{2}$ を検出し， $1100 \mathrm{~K}$ 以 上では $\mathrm{SiCl}$ の脱離を観測した ${ }^{24)}$ 。Shobatakeらは $\mathrm{Cl}_{2} /$ $\mathrm{Si}(111)$ 系で生成物の飛行時間分布を測定し ${ }^{11)}, 700 \mathrm{~K}$ 以 上の表面温度で主に $\mathrm{SiCl}_{2}$ の脱離を検出した。その速度 分布が表面温度に対応した Maxwell-Boltzmann 分布に ほぼ従い，脱離の角度分布が余弦則に従うことは熱脱 離であることを示している。われわれの質量分析では $900 \mathrm{~K}$ 以上でシリコン塩化物の脱離強度が急激に増加す るのが観測された。これら反応温度のばらつきは表面温

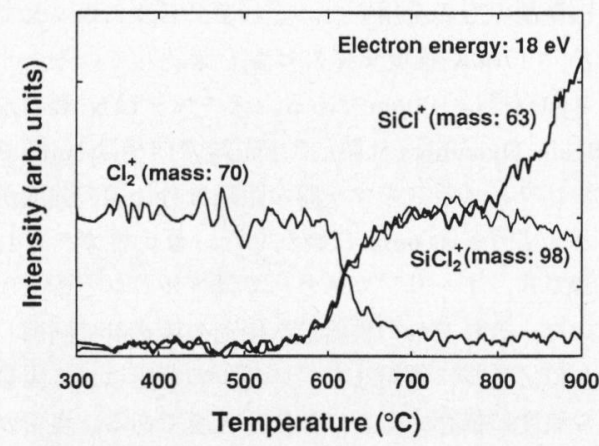

Fig. 3 Intensities of $\mathrm{Cl}_{2}{ }^{+}, \mathrm{SiCl}^{+}$, and $\mathrm{SiCl}_{2}{ }^{+}$ as a function of surface temperature ${ }^{24)}$.

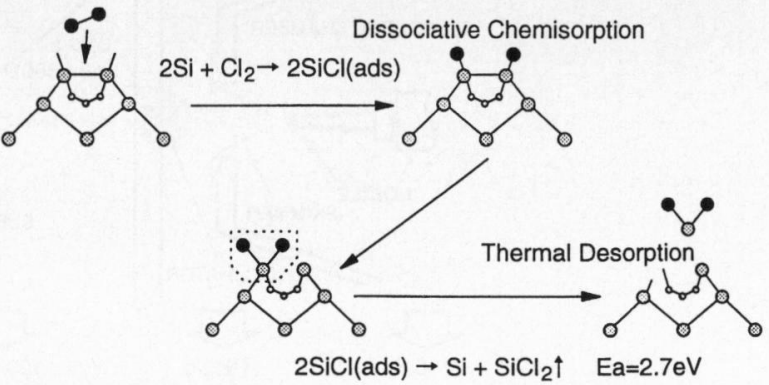

Fig. 4 The surface reaction model for conventional gas etching on $\mathrm{Si}(100)$ surface with thermal energy $\mathrm{Cl}_{2}{ }^{26)}$. 
度の測定法に負うところが大きいと思われる。われわれ の実験では TDS の結果と同じように Si(100) 面と (111) 面の両方で約 $900 \mathrm{~K}$ を熱反応の始まる温度の目安と考え た。これらの反応実験と TDSの結果から，例として $\operatorname{Si}(100)$ 面で起こるエッチング反応をモデル化して Fig. 4 に示す。このモデルではダングリングボンドに結合した 塩素原子が表面拡散し, 局所的に $\mathrm{SiCl}_{2}$ 構造が生成して 熱脱離すると考えた。また，さらに高温では塩素原子が 結合したシリコンのバックボンドが熱解離して直接的に $\mathrm{SiCl}$ が熱脱離するものと考えられる。これら $\mathrm{SiCl} / \mathrm{SiCl}_{2}$ の脱離は分子線の並進エネルギーにかかわらず起こるた め, 本稿では便宜上「通常のガスエッチング」と呼ぶ。

\section{4 加熱ノズル分子線を用いたエッチング反応}

並進エネルギーで誘起される塩素/シリコン系エッチ ングは最初Leoneらによってレーザー蒸発法で発生した 分子線を用いて見出された6)。Fig. 5 に $\mathrm{SiCl}_{3}{ }^{+}$イオンの 検出強度のドーズ依存性を並進エネルギーを変えて測定 した結果を示す。われわれはLeoneらとは独立に通常の ガスエッチングが進行しない $900 \mathrm{~K}$ 以下でエッチレート の並進エネルギー依存性を測定した。その結果をFig. 6 に示す。表面温度が常温のときエッチングは検出されな かったが，800Kでは並進エネルギーで誘起されるエッ チングを観測し， Si(100) 面では $2.1 \mathrm{eV}$ に並進エネル ギー閾值をもつことを見出した (Fig. 6(a) ) 1)。また, poly-Si では並進エネルギー閯值は $0.7 \mathrm{eV}$ であった2)。 $\mathrm{Si}(111)$ 面では $5 \mathrm{eV}$ まで実験を行ったが並進エネルギー 閾值は観測されなかった。このように並進エネルギー閾 值は表面の結晶構造に依存する。

高温ノズルからガスが噴出して断熱膨張する際の振 動緩和は遅いため, 一般には分子線中に振動励起分子 が混入する。Engelらは塩化シリコンの収率のノズル温 度依存性を測定したが, 振動励起の効果は確認されな

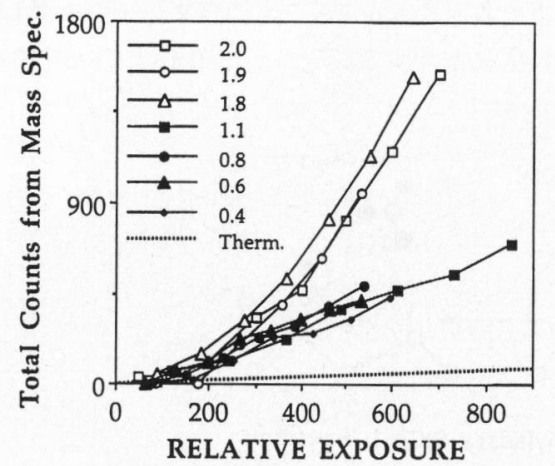

Fig. 5 Plots of total counts of $\mathrm{SiCl}_{3}{ }^{+}$etch product vs. $\mathrm{Cl}_{2}$ exposure obtained at different $\mathrm{Cl}_{2}$ energies 6$)$.
かった 25)。われわれはノズル温度变化法 (Fig. 6(a)の○ 印) とガス混合比変化法 (Fig. 6(a) (c)の・印) の両方で 並進エネルギー閾值を調べたが1)，Fig.6(a)に示したよ うに両者にほとんど差は認められず，エッチレートに対

して振動エネルギーの効果は観測されていない。

Fig. 6(b) に示したように，ガスエッチングが始まる $900 \mathrm{~K}$ 以上の表面温度でもエッチレートが並進エネルギー に依存して増加する様子が観測された ${ }^{26)}$ 。実験誤差のた
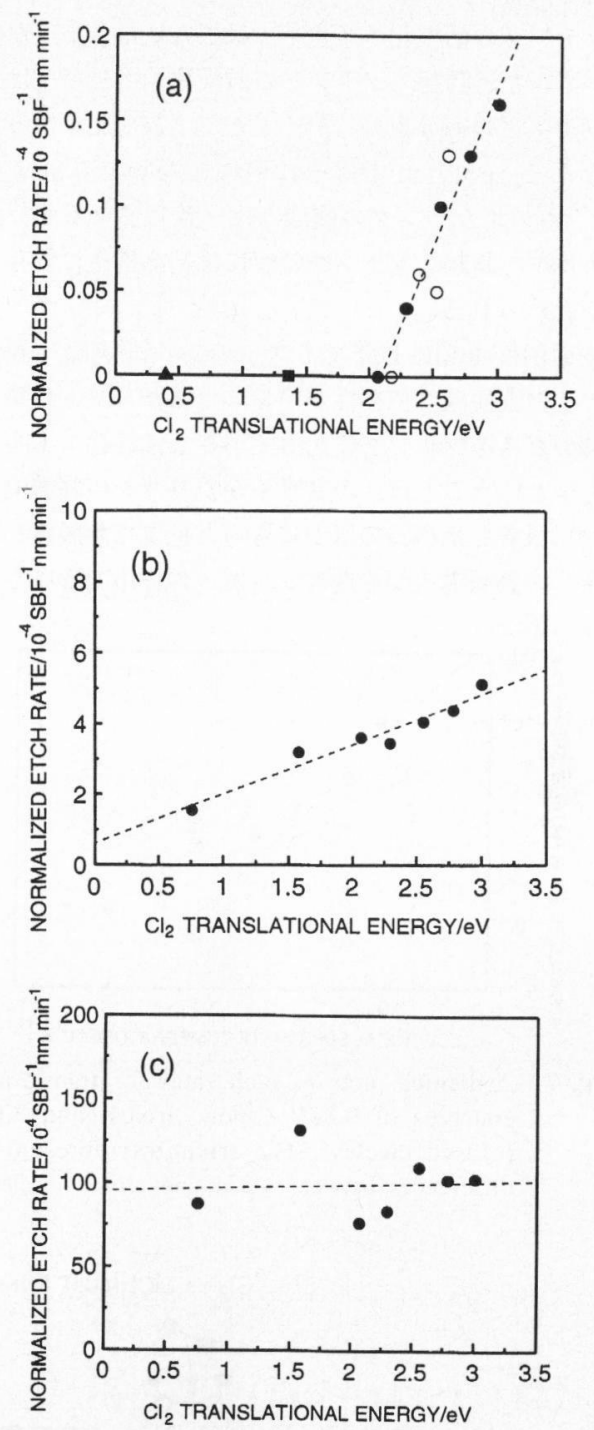

Fig. 6 Translational energy dependence of etch rates in the $\mathrm{Cl}_{2} / \mathrm{Si}(100)$ at the surface temperature of (a) $800 \mathrm{~K}$, (b) $990 \mathrm{~K}$, and (c) $1090 \mathrm{~K}$, respectively. The nozzle temperature was maintained at $1180 \mathrm{~K}$ in closed markers. The $\mathrm{Cl}_{2}$ translational energy was controlled by changing mixing ratio of the gases 26 ). 
め，並進エネルギー䦨值が表面温度に依存するか否かは 明確ではない。約 $1100 \mathrm{~K}$ の高温ではガスエッチングの 寄与が大部分を占めるため，見かけ上エッチレートは並 進エネルギーに依存しなくなる (Fig. 6(c))。

一定の並進エネルギーのもとでエッチレートの表面温 度依存性を測定すれば，アレニウスプロットからエッチ ング反応の活性化エネルギーが評価できる。Fig. 7 に並 進エネルギーを閾值以下の $0.8 \mathrm{eV}$ と間值以上の $3.0 \mathrm{eV} に$ 設定して測定したアレニウスプロットを示す26)。ガス エッチングの活性化エネルギーは $2.7 \mathrm{eV}$ と求まった。並 進エネルギー誘起エッチングの活性化エネルギーはガス エッチングの寄与を差し引くことで $1.2 \mathrm{eV}$ と求まった。 ちなみに, poly-Siではそれぞれ $2.8 \mathrm{eV}$ と $0.9 \mathrm{eV}$ であ $り^{2)}$, ガスエッチングの值はほぼ致しているが，並進 エネルギー誘起エッチングの值には結晶構造に依存した 差が認められる。

表面温度 $900 \mathrm{~K}$ 以下でもエッチングが実際に観測さ れ，その表面温度依存性がアレニウスプロットに乗り， 通常のガスエッチングに比べて小さな活性化エネルギー をもつということは，塩素原子がシリコンの終端位置に 1対1で吸着した構造のほかにもっと低温で熱脱離しやす い新しい表面構造が並進エネルギーの作用で形成される

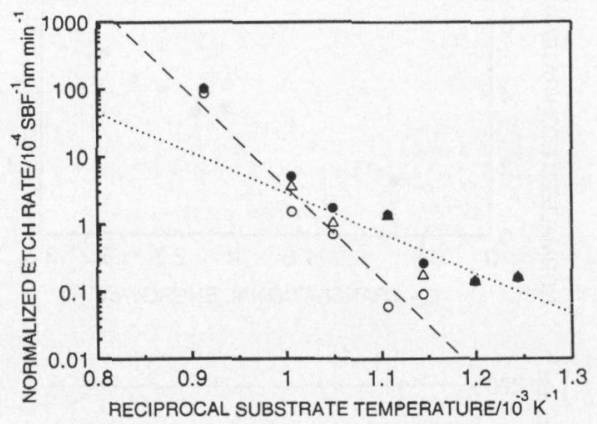

Fig. 7 Arrhenius plots of etch rates for translational energies of $0.8 \mathrm{eV}$ (open circles) and $3.0 \mathrm{eV}$ (closed circles). The triangles represent the differences between open and closed circles $^{26}$ ).
と考えられる。ところで, Yates, Jr. らの TDS 測定20)で は $0.4 \mathrm{ML}$ 以上の被覆率で $500 \sim 600 \mathrm{~K}$ 付近に $\mathrm{SiCl}_{4}$ と同 定された弱い脱離ピークが観測された。Engelらの 測定21)では，ドーズを増すに従って $\mathrm{SiCl}_{3}{ }^{+}$の TDS スペ タトルが $400 \sim 600 \mathrm{~K}$ 付近で台地を示す傾向が観測された ことから, Yates, Jr. らの測定と同様に $900 \mathrm{~K} よ り$ 低温側で $\mathrm{SiCl}_{4}$ の脱離が示唆される。Foord らの観測したTDS スペ クトル22)にも，450Kに $\mathrm{SiCl}_{4}$ と同定されているもう一本の ピーク $(\alpha$ ピーク)が観測されている。闒值以上の並進エ ネルギーをもった塩素分子の入射でシリコン表面にでき る吸着状態はこれらの低温側のピークに対応した表面 状態に類似したものである可能性がある。並進エネル ギーの効果は, 塩素分子が最表面のシリコン二量体ある いはバックボンドをアタックして, $\mathrm{SiCl}_{2}$ あるいは $\mathrm{SiCl}_{3}$ といった高次の塩化シリコン : $\mathrm{SiCl}_{x}(\mathrm{ads})$ を直接または 段階的に生成させるところにあるのかもしれない。その ような吸着表面からは $\operatorname{SiCl}_{x}(x=2-4)$ が比較的低温でも 熱脱離する可能性がある。並進エネルギー閾值はそのよ うな高次の塩化シリコンを形成するために必要なエネル ギー障壁と考えられる。並進エネルギー誘起エッチング の活性化エネルギーが並進エネルギーに依存せず一定で あることから ${ }^{26)}$, その表面構造: $\mathrm{SiCl}_{x}(\mathrm{ads})$ は並進エネ ルギーによらず同質のものと考えることができる。実 測した小さい活性化エネルギー $1.2 \mathrm{eV}$ は，この局所的 $\mathrm{SiCl}_{x}(\mathrm{ads})$ 構造から $\mathrm{SiCl}_{x}$ が熱脱離する過程の活性化工 ネルギーであると解釈している。並進エネルギー誘起 エッチングをモデル化して Fig. 8 に示す。

\section{5 エッチング形状}

通常のガスエッチングを進めると, 多結晶シリコンで は等方的, (100) 単結晶では (111) ファセットが現れる 異方性形状となる。ところが, 並進エネルギー誘起エッ チングを利用することで，垂直に近いエッチング形状を 得ることができる。表面温度が $900 \mathrm{~K}$ 以下の場合には閾 值以上の並進エネルギーをもつ塩素分子のみが 1 次衝突 面で反応に寄与する。その反応確率は $\mathrm{Cl}_{2} / \mathrm{Si}(100)$ 系の

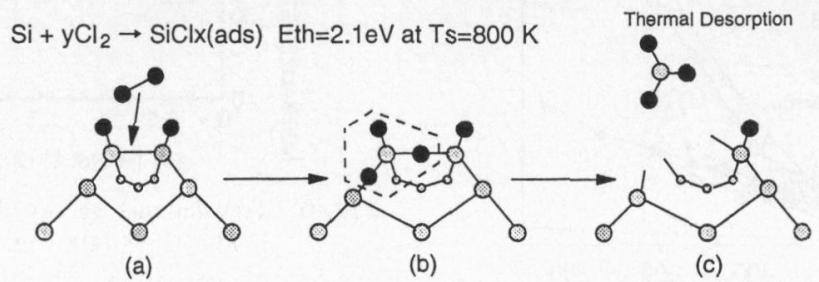

$\mathrm{SiCl}(\mathrm{ads}) \rightarrow \mathrm{SiCly}($ ads $)+\mathrm{SiCl} \uparrow \quad \mathrm{Ea}=1.2 \mathrm{eV}$

Fig. 8 The surface reaction model for translational-energy-induced etching on $\mathrm{Si}(100)$ surface by hyperthermal incident energy $\mathrm{Cl}_{2}{ }^{26}$ ) 


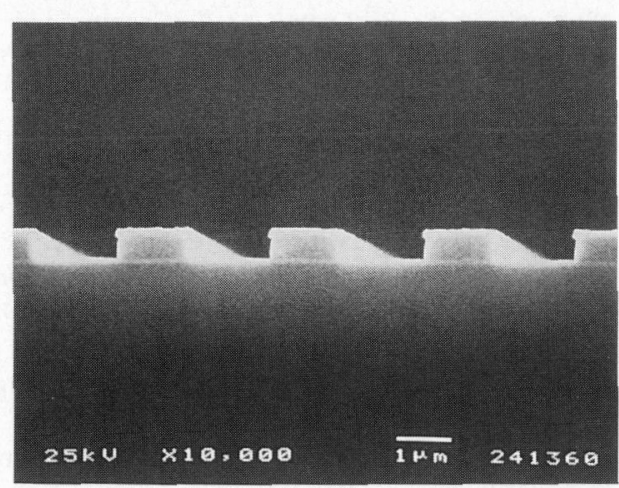

Fig. 9 The SEM micrograph of poly-Si with $\mathrm{SiO}_{2}$ mask, etched by $3.0 \mathrm{eV}$ translational energy $\mathrm{Cl}_{2}$ molecules at the surface temperature of $940 \mathrm{~K}^{2)}$.

場合には $1 \%$ 以下であるので，制御性よく原子レベルの 加工ができる。また，大部分の塩素分子は表面で散乱 し，その際に運動量移行で並進エネルギーをある程度失 う。散乱分子の一部はエッチング側壁に斜めに入射する ため, 垂直方向の並進エネルギー成分は小さい。このた め, 側壁に入射する分子の並進エネルギーは反応間値を 越えないことが期待される。したがって，1次衝突する 底面でのみエッチングが進行して, 側壁では吸着に留ま るため,エッチング形状が垂直に近くなる。Fig. 9 に並 進エネルギー $3.0 \mathrm{eV}$, 表面温度約 $940 \mathrm{~K}$ で poly-Si をエッ チングしたときの電子顕微鏡写真を示す ${ }^{2)}$ 。厚さ $100 \mathrm{~nm}$ の 酸化シリコンをマスクとし, 500nm の poly-Si層がエッ チングされて下地の酸化シリコン層が露出している。こ の温度ではガスエッチングも約 $1 / 3$ 寄与するためにマス ク直下に若干アンダーカットが見られるが，垂直性は大 いに改善された。一方，(100)面のエッチングでは若干 の順テーパ形状を示したものの1)，ガスエッチングによ る大きなアンダーカットと(111) ファセットは観測され ず，方向性のあるエッチングが実現できている。

\section{4. 塩素原子線によるエッチング反応}

ノズル温度を $1300 \mathrm{~K}$ 程度以上にすると塩素分子の熱 分解で生成した塩素原子が分子線に混合する様子が質 量分析器で確認できるようになる。われわれは基板温度 を $900 \mathrm{~K}$ 以下に設定することでガスエッチング反応を抑 制し，かつ塩素分子の並進エネルギーを $2 \mathrm{eV}$ 以下に限定 することで分子による並進エネルギー誘起エッチングを 抑制する条件のもとで，塩素原子の混合した分子線を $\operatorname{Si}(100)$ に照射し，塩素原子線によるエッチングを観測 した ${ }^{27)}$ 。その収率は分子線による並進エネルギー誘起 エッチングに比べて 2 けた程度大きい。
Matsuo らのXPS 測定17)では塩素原子を照射したSi(100) 面には $\mathrm{SiCl}_{3}$ や $\mathrm{SiCl}_{4}$ に帰属される $\mathrm{Si}(2 \mathrm{p})$ のサブピーク が報告されていることから，塩素原子は熱エネルギー程 度の並進エネルギーでも容易に Si-Si 結合間に侵入する ものと思われる。原子混合分子線を $110 \mathrm{~K}$ の Si(100) 面 に照射して測定したEngelらのTDSスペクトルでは21), $200 \mathrm{~K}$ 付近の脱離ピーク群と $600 \mathrm{~K}$ 付近のブロードな ピークを $\mathrm{SiCl}_{4}$ と同定している。Karahashi らは表面温 度 $900 \mathrm{~K}$ 以下で主生成物は $\mathrm{SiCl}_{2}$ であると報告している が10), 表面温度が $420 \mathrm{~K}$ から $720 \mathrm{~K}$ の範囲で低温ほど $\mathrm{SiCl}_{3}$ と $\mathrm{SiCl}_{4}$ の収率が大きくなることが確認されてい る。このように脱離する塩化シリコンの種類は表面温度 に大きく依存する。低温では $\mathrm{SiCl}_{2}$ は熱脱離しにくいた め $\mathrm{SiCl}_{3}$ や $\mathrm{SiCl}_{4}$ まで塩化が進行し, 逆に高温では高次 の塩化が進行しないうちに $\mathrm{SiCl}_{2}$ として熱脱離すると考 えると定性的にこれらの実験結果を説明できる。

さらに，われわれの測定ではエッチレートが原子の並 進エネルギーに依存して増加する様子が観測された27)。 また, 塩素原子の並進エネルギーが $0.3 \mathrm{eV}$ の場合, 活性 化エネルギーは $0.7 \mathrm{eV}$ であり, 分子線による並進エネル ギー誘起エッチングのそれより小さいこともわかってき ている27。一方，Karahashiらの実験では分子線による 並進エネルギー誘起エッチングと原子エッチングとで 活性化エネルギーは変わらず $0.2 \mathrm{eV}$ と報告されてい る28)。われわれはエッチング深さを測定するのに対し て, Karahashiらは $\mathrm{SiCl}_{2}{ }^{+}$をニタしている点に起因す るものと考えているが, 数值そのものが両者で大きく異 なる原因は不明である。

\section{5. エッチレートの被覆率依存性と吸着形態}

Engel らはエッチング中の表面の塩素被覆率と $\mathrm{SiCl}_{2}$ の脱離速度との相関を調べて, $\operatorname{Si}(111)$ 面では 2 次の依 存性を, $\mathrm{Si}(100)$ 面では $0.5 \mathrm{ML}$ にブレイクのある1次の 依存性を観測した ${ }^{25)}$ 。Karahashiらも活性化エネルギー が塩素被覆率に依存することを報告している10)。Fig. 4 に通常のガスエッチングのモデルを単純に示したが、こ れらの結果はこのモデルを越えた複雑な反応機構を示唆 している。

最近, Kummelらは並進エネルギーを指定して塩素分 子を吸着させた Si(111) 表面を, 走査トンネル顕微鏡 (STM) を用いて in-situ で観測した ${ }^{29)}$ 。直接的な解離吸 着と前駆体経由の化学吸着が両方ともほほ等率で起こる 並進エネルギー $0.11 \mathrm{eV}$ では，前者に起因する孤立した 原子状吸着と後者による島状吸着が観測された。さら に, 直接的な解離吸着が支配的な並進エネルギー $0.44 \mathrm{eV}$ では，塩素原子が隣合うアドアトムに1個ずつ対を成し 
て吸着している様子 (pair-adsorption) が観測された。こ のような原子レベルの解像度をもつ表面観察手段の高度 化と普及は, 今後, 表面反応機構の理解に大きく貢献す るものと期待される。

\section{6. ま と め}

本稿では並進エネルギーを制御した塩素分子線とシリ コンとの表面反応について最近の研究例を紹介した。加 熱ノズルを用いたシード分子線技術を利用すれば， $5 \mathrm{eV}$ 程度まで塩素分子の並進エネルギーを連続的に変化させ ることができる。塩素分子/シリコン単結晶系の初期付 着確率の並進エネルギー依存性には, 前駆体経由の化学 吸着と直接的活性吸着を反映して極小が現れる。解離吸 着で形成される単原子層は $900 \mathrm{~K}$ 程度まで保持される。 ガスエッチング反応はそれ以上の表面温度で起こり, $\mathrm{SiCl}_{2}$ が熱脱離する。 $\mathrm{Si}(100)$ 面の場合, ガスエッチング の活性化エネルギーは $2.7 \mathrm{eV}$ である。ガスエッチングが 起こらない $900 \mathrm{~K}$ 以下でも並進エネルギー $2.1 \mathrm{eV}$ 闇值 として塩化シリコンが熱脱離する。並進エネルギーの効 果は新しい塩素吸着構造が形成されるところにあると解 釈している。並進エネルギー閾值はそのような構造を形 成するためのエネルギー障壁と思われる。塩素原子線に よるエッチングも並進エネルギーで増速される。その収 率は分子線による並進エネルギー誘起エッチングより 2 けた程度大きい。最近では，並進エネルギーを指定して 形成した吸着表面をin-situ でSTM観察することも試み られている。今後はこのような吸着表面の微視的構造の 評価が進み, 反応機構の理解が一層進むものと期待され る。

\section{文 献}

1) Y. Teraoka and I. Nishiyama : Appl. Phys. Lett. 63, 3355 (1993).

2) Y. Teraoka and I. Nishiyama : Jpn. J. Appl. Phys. 33, 2240 (1994).

3) J. B. Anderson, R. P. Andres and J. B. Fenn : "Molecular Beams" ed. by J. Ross (John Wiley \& Sons, Inc. New York, 1966) p. 275.

4) 正畠宏祐, 篠原久典：分光研究 39, 187 (1990).

5) 正畠宏祐：“新実験化学講座 分光 III”（丸善，1993） p. 107.

6) F. X. Campos, G. C. Weaver, C. J. Waltman and S. R. Leone : J. Vac. Sci. Technol. B10, 2217 (1992).

7) G. C. Weaver and S. R. Leone : submitted to
Surf. Sci. ; S. R. Leone, F. X. Campos and G. C. Weaver : Proc. of Symp. on Dry Process (Tokyo, 1994) p. 85.

8) J. B. Cross, L. H. Cremers, L. H. Spangler, M. A. Hoffbauer and F. A. Archuleta : Proc. of 15 th Int. Symp. on Rarefied Gas Dynamics (Grado, Italy, 1986) p. 657.

9) K. P. Giapis, T. A. Moore and T. K. Minton : Proc. of American Vacuum Society $41 \mathrm{st}$ Nat. Symp. (Denver, USA, 1994) p. 277.

10) K. Karahashi, J. Matsuo and K. Horiuchi : Jpn. J. Appl. Phys. 33, 2252 (1994).

11) H. Yoshikawa and K. Shobatake : Chem. Phys. Lett. 223, 341 (1994).

12) D. A. King and M. G. Wells : Surf. Sci. 29, 454 (1972).

13) D. J. D. Sullivan, H. C. Flaum and A. C. Kummel : J. Phys. Chem. 97, 12051 (1993).

14) P. Gupta, P. A. Coon, B. G. Koehler and S. M. George : Surf. Sci. 249, 92 (1991).

15) D. Purdie, N. S. Prakash, K. G. Purcell, P. L. Wincott and G. Thornton : Phys. Rev. B48, 2275 (1993).

16) L. S. O. Johansson, R. I. G. Uhrberg, R. Lindsay, P. L. Wincott and G. Thornton : Phys. Rev. B42, 9534 (1990).

17) J. Matsuo, K. Karahashi and A. Sato : Jpn. J. Appl. Phys. 31, 2025 (1992).

18) N. Aoto, E. Ikawa and Y. Kurogi : Surf. Sci. 199, 408 (1988).

19) T. Ohno : Phys. Rev. Lett. 70, 962 (1993).

20) Q. Gao, C. C. Cheng, P. J. Chen, W. J. Choyke and J. T. Yates, Jr. : J. Chem. Phys. 98, 8308 (1993).

21) A. Szabo, P. D. Farrall and T. Engel : Surf. Sci. 312, 284 (1994).

22) R. B. Jackman, H. Ebert and J. S. Foord : Surf. Sci. 176, 183(1986).

23) R. J. Madix and J. A. Schwarz : Surf. Sci. 24, 264 (1971).

24) K. Karahashi, J. Matsuo and S. Hijiya : Appl. Surf. Sci. 60/61, 126 (1992).

25) A. Szabo and T. Engel : J. Vac. Sci. Technol. A12, 648 (1994).

26) Y. Teraoka and I. Nishiyama : submitted to J. Chem. Phys.

27) Y. Teraoka and I. Nishiyama : Proc. of 16th Symp. on Dry Process (Tokyo, 1994) p. 93. ; submitted to J. Appl. Phys.

28) K. Karahashi, J. Matsuo and K. Horiuchi : Proc. of 16th Symp.on Dry Process (Tokyo, 1994) p. 99.

29) C. Yan, J. A. Jensen and A. C. Kummel : J. Chem. Phys. 102, 3381 (1995). 